\title{
DISASTER COMMUNICATION BASED ON LOCAL WISDOM AT DISASTER PRIED AREAS
}

\author{
${ }^{*}$ Mira Hasti Hasmira ${ }^{12}$ \\ ${ }^{*}$ Department of Sociology - Universitas Negeri Padang - Indonesia \\ ${ }^{2}$ Doctoral Program in Environmental Science, Universitas Negeri Padang - Indonesia \\ email: mirahasti@fis.unp.ac.id
}

*Corresponding Author, Received: March 8, 2021. Revised: March 21, 2021. Accepted: May 20, 2021

\begin{abstract}
Based on its location, Indonesia is very unique because it is prone to disasters. In disaster prevention and management efforts, disaster communication related to the government and communities in disaster-prone areas is required. To expedite the communication process that occurs, the government needs to increase knowledge and understanding of the local wisdom of the local community regarding the environment. This is important to increase public trust so that what is intended through disaster communication can be achieved.
\end{abstract}

Keywords: Communication, Disaster, Mitigation, Risk

(c) (i) (O) This work is licensed under the Creative Commons Attribution-ShareAlike 4.0
International License

\section{INTRODUCTION}

Based on its location, Indonesia is very unique. It is flanked by two continents, namely the Asian and Australian Continents, and is above the meeting of the earth plates which are the three main tectonic plates. This causes Indonesia to be always vulnerable to natural disasters. In the last eight years, there have been many disasters with large and small impacts on the environment in Indonesia [1].

Disaster is a collection of two symptoms, namely natural and non-natural symptoms that cause discomfort or unrest in the community. Impact frequent disasters in Indonesia make disasters into topic frequently discussed and should be addressed immediately [2]. For this reason, efforts in disaster management or control are urgently needed [3]. Write that disaster management is an effort related to prevention, taming, rescue, rehabilitation, and reconstruction. These efforts were made in the period before, during, or after the disaster. The implementation of these efforts is carried out systematically, thoroughly, and efficiently in the use of resources and can effectively assist victims of the community [3].

In dealing with and minimizing the risk of disasters to humans, the role of communication is very large. Furthermore, this paper will examine more about communication in disaster mitigation.

In the General Guidelines for Disaster Mitigation, Attachment to the Regulation of the
Minister of Home Affairs No. 33/2006 dated 18 October 2006, it is written that there are four important things in disaster mitigation, namely: 1) information and maps of disaster-prone areas for each type of disaster are available; 2) socialization to increase public understanding and awareness in dealing with disasters, because they live in disaster-prone areas; 3) knowing what needs to be done and avoided, as well as knowing how to save oneself if a disaster occurs, and 4) organizing and structuring disaster-prone areas to reduce the threat of disasters. The four important points in disaster mitigation mentioned above talk about the importance of communication in disaster mitigation. About mitigation, communication is needed to reduce uncertainty in the community so that more effective and definite actions can be taken to eliminate casualties.

To obtain a small disaster risk, it must be optimally supported not only by a hard power approach but also with a soft power approach, namely by providing information about disasters with outreach to the community [4]. Preparing the community, especially in disaster-prone areas through disaster communication, ideally, should start from a pre-disaster situation, not in a disasterprone condition [5].

Paton, McClure, and Bürgelt stated that in disaster-prone areas, the main purpose of disaster communication is to encourage people to understand and take protective measures (for example storing food and drink, securing essential items at home, and preparing and developing an 
emergency plan in each house) before the disaster happened. This preparation is done to reduce the risk of injury, death, and damage to buildings as well. To find out whether this activity can be understood and interpreted properly by the community, it is very important to be able to distinguish between understanding and meaning. For example, information through disaster communication can be understood by the public but may be meaningless if the community believes that the actions taken are unlikely to improve the risk of harm [6].

\section{RESEARCH METHODS}

This study was conducted with methods to book early. The research literature is the research conducted by utilizing the literature (literature), such as by utilizing books, records, or even report the study conducted se Previously. [7] stated that the investigators of the library are those with expertise in English literature, sociology of history, and musicology. Humanists and social humanist scientists make libraries as laboratories, unlike natural scientists when using libraries, but not as their laboratories.

This paper is social research because it focuses more on what problems the government and NGOs should do when implementing disaster communication to the community. The data collection method used was to start by identifying books, articles, and the internet. After the data were obtained, descriptive analysis was carried out. Methods of analysis descriptive ie an effort to collect and rearrange some of the data, and then analyze the data.

\section{RESULTS AND DISCUSSION}

For that, I first need an understanding of disaster management. Shaw in stating that the aspects covered in disaster management are [8] below.

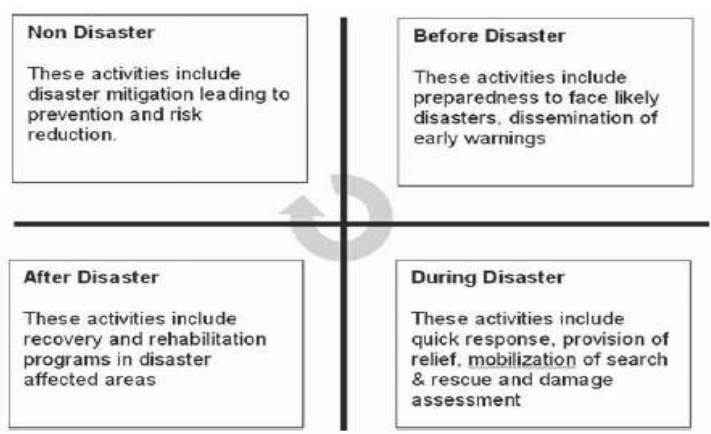

Fig. 1 Management disaster
In the above [Fig 1] section it can be understood that disaster management includes conditions before, during, after a disaster event as well as non-disaster situations. In a non- disaster situation, this is a description of the mitigation process.

[9] also presented specifically on the issue of communication in disaster management, as outlined in the following [Fig 2] chart.

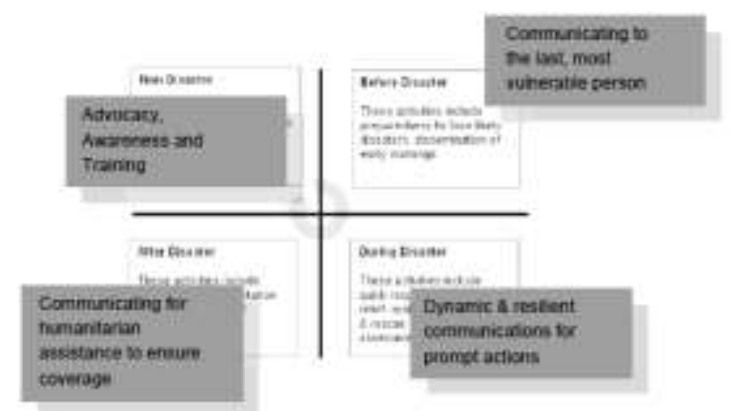

Fig. 2 The issue of communication in disaster management

What communication is most needed in the disaster mitigation process?

[10] wrote that there are stages in a communication process, starting with the process of forming messages, delivering messages, receiving messages, and processing messages. These processes occur in one and or two people more according to the purpose of the communication [11].

Still in [11], [12] states that communication can work as intended if there is a relationship or link of interest and interest between the person sending the message (communicator) and the person receiving the message (communicant). For this reason, there must be equality in terms of reference and actors in the communication process. In this case, the similarities are related to the level of education, knowledge, cultural background, interests, orientation. The link of interests and interests will be greater if the level of equality in the frame of reference for communicators and communicants is also greater. This will make communication easier.

In disaster communication, the government as a communicator in conveying messages to people in disaster-prone areas must find things that can link interests and interests with community members. One of them is by understanding the environment according to the community's perspective, which is known as local environmental wisdom.

Colored said that local wisdom is a set of knowledge contained in a community, which originates from previous generations. This local wisdom is also an experience related to experiences related to the environment and other 
communities to solve the problems faced. It is further stated that local wisdom can be understood through advice which is learned from generations to serve as a guide for life [13].

Local wisdom in the environment is also recognized in the law. According to the Law of the Republic of Indonesia No. 32/2009 concerning Environmental Protection and Management, local wisdom is the noble values that apply in the order of community life to, among others, protect and manage the environment in a sustainable manner. Local wisdom will always be connected to human life who lives in a wise environment. Because the living environment is a unitary space with all the objects in it, both living and inanimate objects.

[14] states that the culture and local wisdom adopted by the community affects the perspective of a community group towards God, the environment, and others so that about disaster mitigation, this aspect needs to be considered to support the effectiveness of emergency and postdisaster response programs. However, this aspect of culture and local wisdom is often seen as something static. Both are dynamic things. Local culture and wisdom are not a single variable in disaster mitigation efforts. The existence of technology and policy aspects are other variables in disaster mitigation efforts [15].

This means that people, especially those who live in disaster-prone areas, have a way that they believe will be able to tell them when a disaster will occur. There are symbols that they understand their meaning in translating nature.

Tabel 1. Belief in Natural Symbols [1]

\begin{tabular}{|c|c|}
\hline Symbol & Trust \\
\hline $\begin{array}{l}\text { Animals (birds, } \\
\text { fish, wild } \\
\text { animals) }\end{array}$ & $\begin{array}{l}\text { It is believed to be a sign of } \\
\text { season, location, symbol of } \\
\text { welfare and a sign of a } \\
\text { dangerous area or not. }\end{array}$ \\
\hline $\begin{array}{l}\text { Rice, coffee, } \\
\text { vegetables }\end{array}$ & $\begin{array}{l}\text { It is believed to be an identity } \\
\text { symbol of prosperity and } \\
\text { power. }\end{array}$ \\
\hline Tunggu Tubang & $\begin{array}{l}\text { Believed as identity, identity, } \\
\text { a symbol of power and pride. }\end{array}$ \\
\hline House on stilts & $\begin{array}{l}\text { Believed to provide protection } \\
\text { against natural threats, a } \\
\text { symbol of identity and social } \\
\text { status, }\end{array}$ \\
\hline $\begin{array}{l}\text { Rice fields, } \\
\text { hills, forests, } \\
\text { rivers }\end{array}$ & Tuha grace Trust $n$ \\
\hline
\end{tabular}

Next, in Indonesian society, it is not something new if a mountain has one of the community leaders who is trusted to be the guardian of the mountain (caretaker) and its forest area. For example, Mr. Tata Mandong is the guardian of Mount Bawakaraeng, South Sulawesi. The most phenomenal is Mbah Maridjan, whose real name is Raden Ngabehi Surakso Hargo. He holds the mandate as a caretaker because of the orders of Sri Sultan Hamengkubuwana IX. When Mount Merapi erupts, residents will only evacuate if there is a command from Mbah Maridjan. After the death of Mbah Maridjan due to the eruption of Mount Merapi in 2010, Mbah Asih (Kliwon Suraksohargo Asihono) was appointed by the Ngayogyakarto Palace in April 2011 to replace Mbah Maridjan's duties.

When a disaster occurs, such as the eruption of Mount Merapi in Yogyakarta, the community refers more to the opinion of the people they trust as the caretaker of the mountain to decide when to evacuate or not even at all. The community appealed to BNPB as the official government agency in disaster management as a second opinion to follow.

Mount Merapi key interpreters have the main duty as a leader related to rituals related to Mount Merapi. The balance between the Javanese kingdom and the power of the magical kingdoms on Mount Merapi is the purpose of these rituals. The Labuhan salvation ritual is held once a year on the 30th of Rajab (Javanese calendar). This ritual is marked by giving offerings to Mount Merapi. This offering is a symbol of gratitude and requests to be given safety to God for the people of Yogyakarta. In addition, the caretaker always provides information to residents in case of activity on Mount Merapi. Whereas for Mount Merapi climbers, the existence of a caretaker is very meaningful. A locksmith always provides information to climbers regarding what restrictions climbers should avoid, providing information about climbing routes and rescue routes [16].

Based on this, the author argues that communication that is important in mitigation and disaster risk management is communication-based on an approach to the community. When the government is about to conduct socialization on disaster mitigation, it is important to understand the local wisdom of the community regarding the environment and to personally approach community leaders who are used as references by the community in making decisions when a natural disaster occurs. Trustor trust is the essence in initiating this communication. Trusting in natural language and community leaders in disaster-prone areas will make it easier to conduct socialization for disaster mitigation. Status is also very important in an effective communication process. If the government "takes advantage" of the status of existing community leaders, it will make communication more effective. [17]

[18], stated that the communication process must be able to answer the questions "who say what, in which channels to whom and with what 
effect". Who refers to who is a communicator. say what refers to the content of the message that is conveyed to be followed or implemented, in which channel refers to the media channel used in the communication process (direct or media), to whom refers to the target or the communicant. and. with hat effect refers to the effect that occurs after the message is conveyed [19].

In this paper, who means the government, which has to say what is related to disaster mitigation, and through what channels (can be direct socialization or media) to the public (whom) in disaster-prone areas in the hope (with what effect) provide understanding to the community about disaster mitigation.

In a disaster, reliable information is essential for effective disaster response action. Affected people rely on information they think can be trusted. It is unlikely that they will pay much attention and act on certain information provided by someone they do not trust - a situation that will prevent the transformation of the information provided into usable knowledge [20-24]. Therefore, in disaster communication, building trust and trust is a necessary prerequisite for rapid decision-making in a crisis [25, 26]. Trust helps increase the feasibility of information in the eyes of affected people, and in improving the overall quality of the communication process, and in the efficiency of the information retrieval process [27].

Trust is a major determinant of the effectiveness of interpersonal relationships, group processes, and social relationships. Trust only becomes necessary when there is some potential or actual risk for the decision-maker [28]. When faced with natural hazards, all decision-makers must face risks and uncertainties. That belief serves to reduce the uncertainty and complexity that people encounter when faced with new events [29] enhancing its status as a very important construct when faced with unusual, rare, and complex environmental hazards [6].

\section{CONCLUSION}

Through this paper, it is hoped that the government can approach the community through understanding local wisdom in each disaster-prone area so that public trust in the government in disaster management can be increased, especially in providing disaster communication related to disaster mitigation.

\section{ACKNOWLEDGEMENTS}

This writing this literature reviews can be carried out smoothly, because of the help and cooperation of various parties. Therefore, the author would like to thank Prof. Dr. Dedi Hermon,
MP as the Deputy Director II of the Postgraduate Universitas Negeri (also chairman of the course of disaster risk management, disaster mitigation, and Geography Information Systems/GIS in the Doctoral Program in Environmental Science, Universitas Negeri Padang) who have provided the opportunity and time to sharpen the academic ability my, especially in the field of disaster environmental.

\section{REFERENCES}

[1] Sukmono, F G, Wijayanti, Y T, Bajari, A., Gemiharto, I., Wahyudin, U., Karimah, K. E, Widhagdha, M F, Pertiwi, C A, Prihantoro, E., Yusriah, K., Putranto, A., Wijiharto, P., Rasyid, E., Rahmawati, W., Kurniawati, D., Ardiyansah, R., Junaedi, F., Istiyanto, SB, Sjafirah, NA, ... Devi, $\quad$ P. (nd). Environmental Communication and Planning Communication in Indonesia.

[2] Hermon, D. (2012). Hydrometeorological Disaster Mitigation, Padang: UNP Press, 2012.

[3] Lestari, F A, Soesilo, T E B, \& Khaerudin. (2017). The role of communication in the community as an effort to reduce disaster risk (Study of disaster risk reduction in Mount Kelud eruption disaster management, East Java using the System Dynamics method). Journal of Disaster Management Study Program .

[4] Suherman, A. (2018). Strategi Komunikasi Bencana pada Masyarakat Kabupaten Buton Selatan. Medialog: Jurnal Ilmu Komunikasi, 1(2), 10-18.

[5] Rudianto. (2015). Communication in Disaster Management. Symbolic Journal .

[6] Paton, D. (2008). Risk communication and natural hazard mitigation: how trust influences its effectiveness. International Journal of Global Environmental Issues, 8(12), 2-16.

[7] Abbott, A. (2008). Library Research and Its Infrastructure in the Twentieth Century . College \& Research Libraries.

[8] Budi H H S. (2012). Disaster Communication: System Aspects (Coordination, Information and Cooperation). ASPIKOM Journal.

[9] Shaw, R., Sharma, A., \& Takeuchi, Y. (2009). Indigenous knowledge and disaster risk reduction: From practice to policy. Nova Science Publishers, Inc.

[10] Sendjaja, S. D. (1985). Television and Village Communication Patterns: An Exploratory Study on the Role of Television in the Village Communication Patterns in West Java, Indonesia. University of Hawai'i at Manoa. 
[11] Chaeronisa. (2013). Organizational Communication Process . 4 , 1 - 35.

[12] Schramm, W. (1973). Instructional Television in the Educational Reform of El Salvador. Information Bulletin Number Three.

[13] Gunawan. (2015). The Wisdom of the Southern Mera pi Slope Community, Sleman Regency - Yogyakarta Special Region. Socio Informa.

[14] Hoffman, L. (2015). Longitudinal analysis: Modeling within-person fluctuation and change. Routledge.

[15] Ragil, C., Pramana, AYE, \& Efendi, H. (2020). Local Wisdom in Disaster Mitigation in the Slopes of Mount Merapi A Case Study of Cangkringan District, Sleman Regency. Room Design , 3 (1), 10 - 18.

[16] Roskusumah, T . (2013). Disaster Mitigation Communication by the Geological Agency of the Ministry of Energy and Mineral Resources in Merapi Volcano Prov. In Yogyakarta. Journal of Communication Studies.

[17] Hasmira, M. H. (2018). Communication Pattern Between People Who's Manyanda With Family Members Who's Disanda. Science and Environmental Journal for Postgraduate, 1(1), 28-36.

[18] Laswell, H. D. (1948). The structure and function of communication in society. The communication of ideas.

[19] Oktavia, F. (2016). Village Head Interpersonal Communication Efforts in Mediating the Interests of PT. Bukit Borneo Prosperous with the People of Long Lunuk Village. Communication Science.
[20] Fisher, Louis. Presidential war power. University Press of Kansas, 2013.

[21] Jaeger, P. T., Shneiderman, B., Fleischmann, K. R., Preece, J., Qu, Y., \& Wu, P. F. (2007). Community response grids: E-government, social networks, and effective emergency management. Telecommunications Policy, 31(10-11), 592-604.

[22] Sandman, P. M. (1993). Responding to community outrage: Strategies for effective risk communication. AIHA.

[23] Ferrante, P. (2010). Risk \& crisis communication: Essential skills for today's SH\&E professional. Professional Safety, 55(06), 38-45.

[24] Uslaner, E. M. (1999). Democracy and social capital. Democracy and trust, 121-150.

[25] Ohtani, M., Tsukamoto, K., Koizumi, Y., Ohsaki, H., Imase, M., Hato, K., \& Murayama, J. (2013, June). VCCN: Virtual content-centric networking for realizing group-based communication. In 2013 IEEE International Conference on Communications (ICC) (pp. 3476-3480). IEEE.

[26] Jacobs, W. M., Reinhardt, A., \& Frenkel, D. (2015). Communication: Theoretical prediction of free-energy landscapes for complex self-assembly.

[27] Moorthy, R., Ben ny, G., \& Gill, SS (2018). Disaster communication in managing vulnerabilities. Journal of Communication: Malaysian Journal of Communication.

[28] Coleman, J. S. (1990). Commentary: Social institutions and social theory. American Sociological Review, 55(3), 333-339.

[29] Siegrist, M., \& Cvetkovich, G. (2000). Perception of hazards: The role of social trust and knowledge. Risk analysis, 20(5), 713720 . 